\title{
A Rare Case of Intracerebral Hemorrhage due to Arteriovenous Malformation Located at Petrous Portion of the Temporal Bone
}

\author{
Temporal Kemik Petröz Bölüm Yerleşimli Arteriovenöz Malformasyona \\ Bağlı Intraserebral Kanamalı Nadir Bir Olgu
}

\author{
Emre Cemal GOKCE ${ }^{1}$, Berker CEMIL ${ }^{1}$, Ismail KIRBAS ${ }^{2}$, Alper BOZKURT ${ }^{2}$, Bulent ERDOGAN ${ }^{1}$ \\ ${ }^{1}$ Turgut Ozal University, Faculty of Medicine, Department of Neurosurgery, Ankara, Turkey \\ ${ }^{2}$ Turgut Ozal University, Faculty of Medicine, Department of Radiology, Ankara, Turkey
}

Corresponding Author: Emre Cemal GOKCE / E-mail: emrecemalgokce@yahoo.com

\begin{abstract}
Primary intraosseous arteriovenous malformations (AVM) are not infrequently encountered. We report a case of intraosseous arteriovenous malformation arising in the left temporal bone. A 51-year-old male patient presented with loss of conscious. Computerized tomography displayed hematoma measuring $4 \mathrm{~cm}$ in diameter in the left temporal lobe. Digital subtraction angiography (DSA) showed that a temporal bone AVM supplied by all the branches of the external carotid artery and vertebral artery. Many treatment modalities can be considered for preoperative steps and/or for definitive treatment. We preferred embolisation for this vascular pathology. To the best of our knowledge this represents the first case of an intraosseous arteriovenous malformation located in the temporal bone.
\end{abstract}

KEYWORDS: Endovascular embolization, Intraosseous arteriovenous malformation, Temporal bone

öz

Primer intraosseöz arteriovenöz malformasyonlar (AVM) oldukça nadir görülmektedirler. Bu yazıda, sol temporal kemikte yerleşen primer intraosseoz arteriovenöz malformasyon olgusu sunulmaktadır. 51 yaşında erkek hasta geçici bilinç kaybı şikayeti ile başvurdu. Çekilen tomografide sol temporal lobda $4 \mathrm{~cm}$ çapında hematom saptandı. Yapılan dijital anjiyografide eksternal karotid arterin tüm dallarından beslenen temporal kemik AVM'si tespit edildi. Bu tür malformasyonlarda preoperatif ve kesin tedavi amacıyla uygulanabilecek bir çok tedavi yöntemi bulunmaktadır. Bu vasküler hastalığın tedavisinde embolizasyon ile tedavi yöntemi seçilmiştir. Bildiğimiz kadarıyla temporal kemik yerleşimli ilk intraosseoz AVM olgusu sunulmaktadır.

ANAHTAR SÖZCÜKLER: Endovasküler embolizasyon, Intraosseoz arteriovenöz malformasyonlar, Temporal kemik

\section{INTRODUCTION}

AVM occur as a result of rare congenital embryonal development disorder causing vascular abnormalities consist of connections between arteries and veins without a capillary bed $(6,9)$. Skeletal alterations are commonly associated with vascular malformations $(1,2)$. AVMs often involve soft tissue and bone, and AVMs confined to the bone are extremely rare (8). Intraosseous AVMs occur predominantly in the craniofacial bones, and other skeletal sites have been rarely seen in the literature (10). To our knowledge, we report the first case of temporal bone AVM treated using arterial embolization.

\section{CASE REPORT}

A 51-year-old man was admitted to our emergency department with the complaint of loss of conscious. Neurological examination revealed no abnormalities except mild confusion (Glasgow Coma Scale: 14). The patient underwent cranial tomography confirming the presence of $47 \times 34 \mathrm{~mm}$ hemorrhage in the left temporal lobe at sylvian fissure (Figure $1 \mathrm{~A}-\mathrm{C}$ ). Following cranial tomography, CT angiography had been performed and detected no vascular anomaly. Then, DSA confirmed a large intraosseous arteriovenous malformation located in the temporal bone with multiple feeders from all the branches of the external carotid artery and vertebral artery, draining into cavernous sinus and transverse sinus via deep temporal cortical veins (Figure 2A, B). The AVM was treated by endovascular ONYX embolization (Figure $3 A, B, C$ ). Following the procedure, the patient presented with a grade IV (House-Brachman) facial paralysis and hoarseness. His ear, nose and throat examination revealed left unilateral vocal cord paralysis. Immediately after the complication, methyl prednisolone was given at a dose of $40 \mathrm{mg} /$ day. He was discharged with a grade III facial paralysis and hoarseness after one week of methyl prednisolone treatment. On the $6^{\text {th }}$ month, the patient underwent control angiography. No filling of the AVM was depicted on control images. On neurological examination, only grade I facial paralysis was shown. 


\section{DISCUSSION}

Arteriovenous malformations, which are the result of uncommon errors of vascular morphogenesis between the 4th and 6th weeks of gestation, usually occur intracranially; they are rare outside the cranium and their exact incidence is unknown. However, the most common sites are forehead, nose, ear, and cheek in the extracranium (11). Skeletal changes associated with these intraosseous vascular malformations are common and seen in up to $34 \%$ of cases (2). These changes include bony distortion, destruction, hypertrophy,

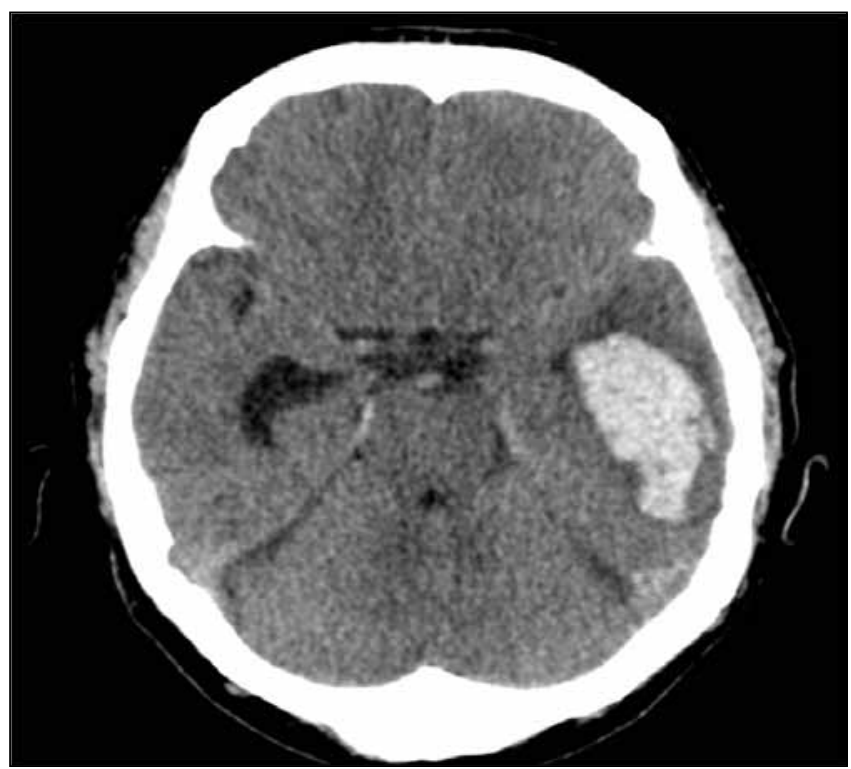

Figure 1: Preoperative cranial CT without contrast agent showing the left temporal lobe hematoma without mass effect. hypoplasia, sclerosis or osteopenia, and primary intraosseous involvement (2); the extent and morphologic features of these changes can be detected on CT scan. Because of the complex anatomy of the temporal bone, subtle bony structures, small canals and fine sutures sometimes cause problems in the differentiation between normal and abnormal (Figure 4A). Arterial vascular anomalies are known as rarities in the temporal bone region. Kosling et al. reported that vascular lesions of temporal bone are less than 1\% (3). Hereby, an AVM located in the petrosal part of the temporal bone was reported which has a temporal cortical venous drainage presented with a temporal lobe hemorrhage. The hemorrhage caused headache and mild confusion without neurological abnormality. Because of the high GCS of the patient, and probability of vascular pathologies such as AVM and/or aneurysm, the authors have not preferred emergency surgical intervention and decided to examine further. CT angiography, a very useful diagnostic test for defining the morphology of vascular anomalies, was performed even after left temporal lobe hemorrhage was detected in computerized tomography. No vascular lesion was depicted on CTA except temporal cortical venous engorgement. DSA was then performed for the diagnosis. Arteriovenous malformation with multiple feeders from external carotid artery and vertebral artery was detected (Figure 2A, B). We hypothesize that temporal lobe hemorrhage from this vascular malformation located at the petrous portion of the temporal bone were due to venous hypertension of these temporal cortical venous structure (Figure 2C).

The management of AVMs remains a challenge for neurosurgeons, and all types of vascular malformation requires a multidisciplinary approach and above all, in patients with
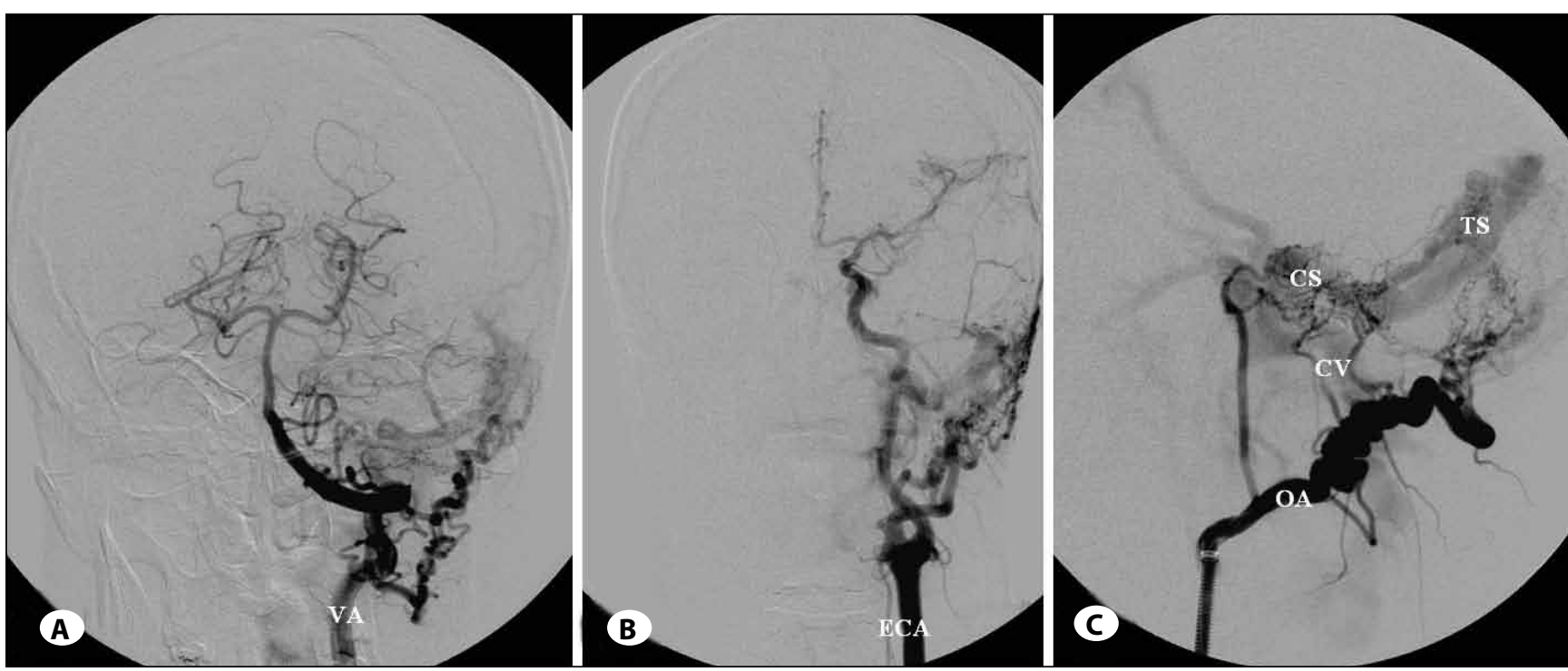

Figure 2: (A) Left external carotid and (B) vertebral artery angiograms before embolization in the mid arterial phase showing a large intraosseous arteriovenous malformation located in the temporal bone with multiple feeders from all the branches of the external carotid artery and vertebral artery. (C) Arteriovenous malformation fed by occipital artery draining into cavernous sinus and transverse sinus via deep temporal cortical veins. (VA: Vertebral artery, ECA: External carotid artery, CS: Cavernous sinus, CV: Cortical vein, OA: Occipital artery). 
bony involvement, treatment is more complicated (4). Various treatment strategies were in use for this disease, including embolization, stereotactic radiosurgery, and microsurgery. But generally, because of the complexity and localization, AVMs often require combinations of these treatment modalities to achieve a complete cure (5). In the English literature, treatment modalities of the temporal bone AVM's have not been evaluated previously. In our case, due to the localization of the vascular malformation in the petrous part of the temporal bone, surgical treatment choice with complication of hearing impairment probability has directed the surgeons to the embolization procedure (Figure 4B). However, this treatment option is not without risk. Potential complications of embolization include puncture site hematoma, arterial dissection, migration of the embolization material, stroke and infection (7). Following the embolization procedure facial paralysis and
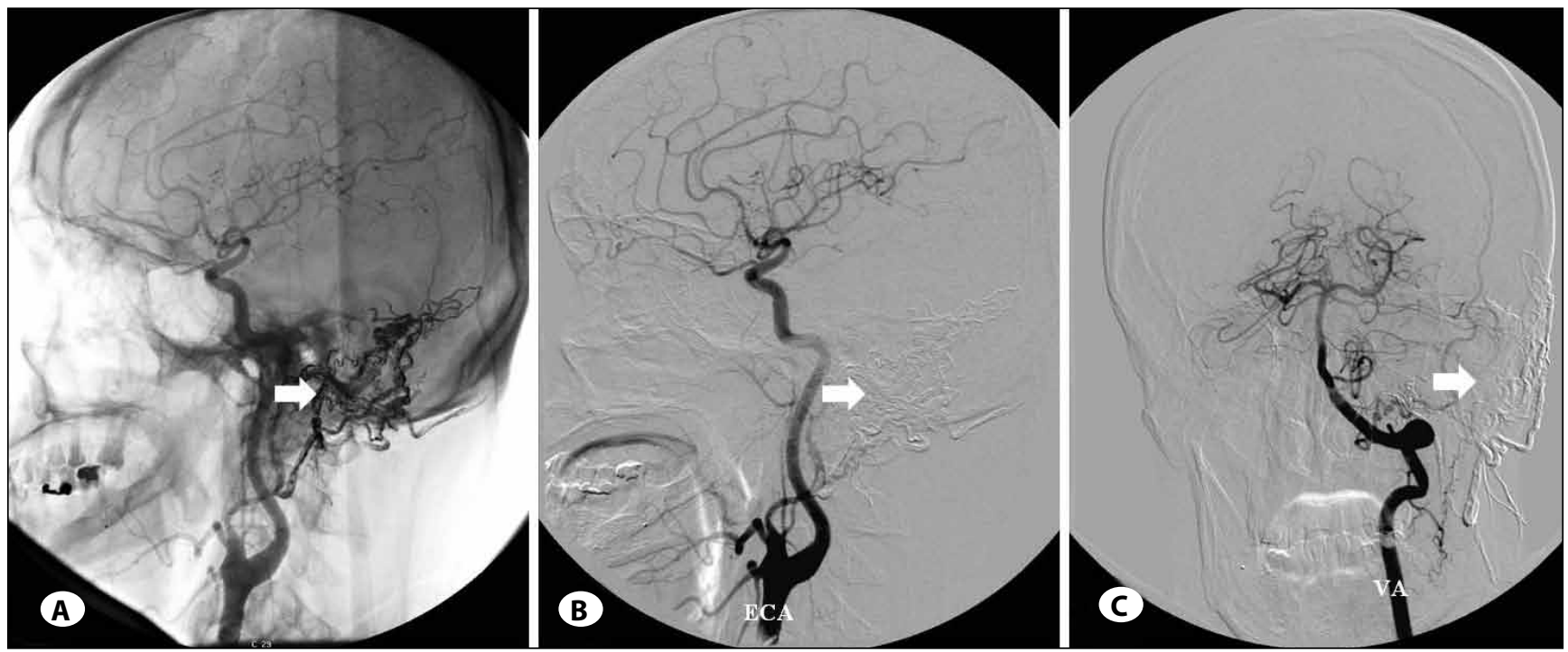

Figure 3: Left external carotid (A, B) and vertebral (C) angiograms showing endovascular ONYX embolization of the arteriovenous malformation. (White arrow: AVM treated with endovascular ONYX embolization).
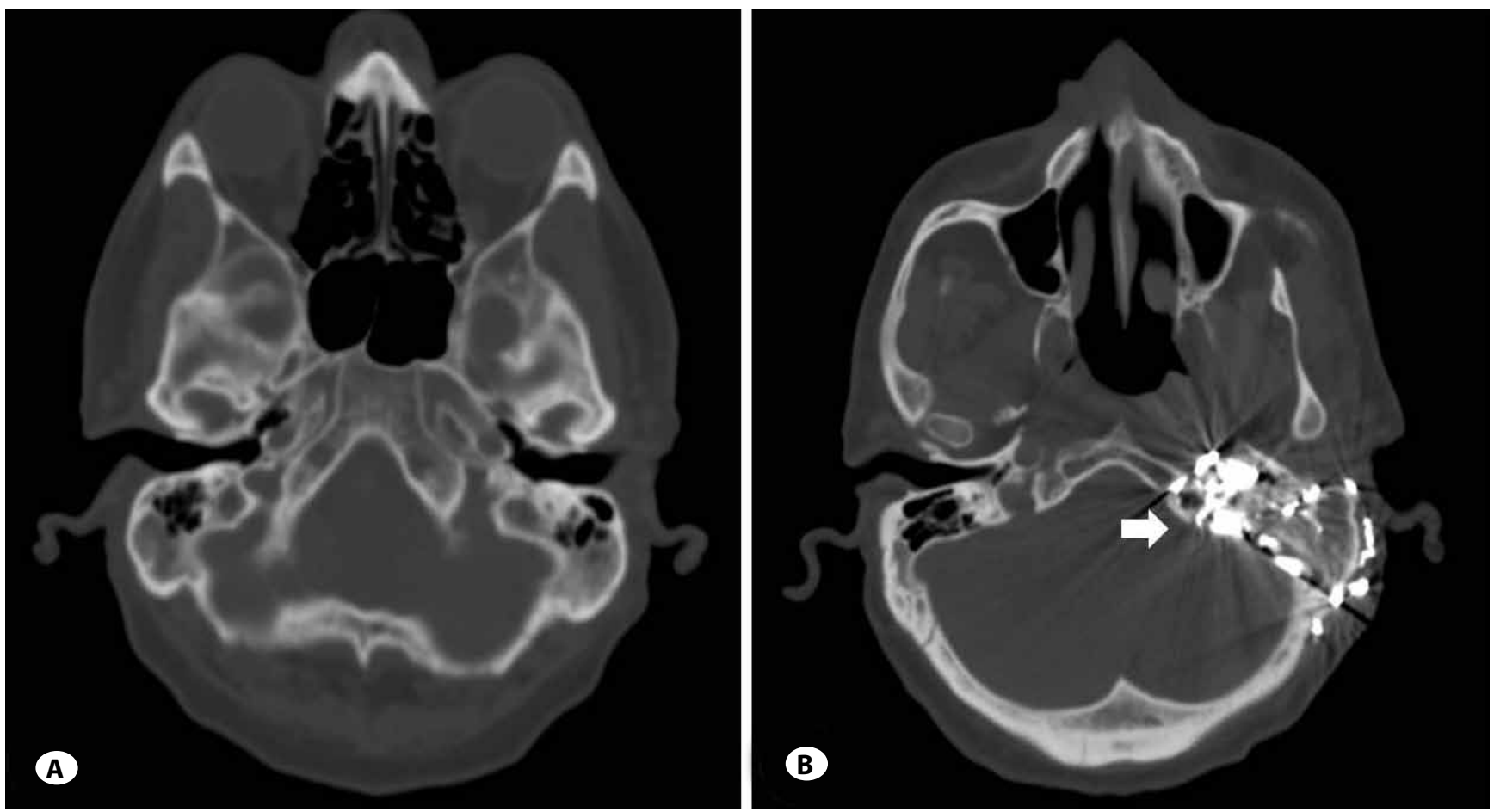

Figure 4: (A) No skeletal changes was detected on bone-window computed tomography. (B) Bone-window computed tomography showing endovascular ONYX embolization of the arteriovenous malformation. (White arrow: AVM treated with endovascular ONYX embolization). 
hoarseness (unilateral vocal cord paralysis) have developed in our patient. We hypothesize that these complications were due to compression of the fasial nerve in the petrous part of the temporal bone, and the vagus nerve extending through the jugular foramen by the embolization material and also reconstitution of the AVM in the post-operative period.

In conclusion, intraosseous AVMs are extremely rare pathologies. We report the first case of temporal bone AVM in the literature. Embolisation could be a first choice of treatment. However, all physicians who would treat temporal bone AVM, should be aware of facial and vocal cord paralysis.

\section{REFERENCES}

1. Boyd JB, Mulliken JB, Kaban LB, Upton J 3rd, Murray JE: Skeletal changes associated with vascular malformations. Plast Reconstr Surg 74(6): 789-797, 1984

2. Breugem CC, Maas M, Breugem SJ, Schaap GR, Van der Horst CM: Vascular malformations of the lower limb with osseous involvement. J Bone Joint Surg Br 85(3): 399-405, 2003

3. Koesling S, Kunkel P, Schul T: Vascular anomalies, sutures and small canals of the temporal bone on axial CT. Eur J Radiol 54(3): 335-343, 2005

4. lerardi AM, Mangini M, Vaghi M, Cazzulani A, Mattassi, R, Carrafiello G: Occlusion of an intraosseous arteriovenous malformation with percutaneous injection of polymethylmethacrylate. Cardiovasc Intervent Radiol 34: 150-153, 2011
5. Chang SD, Marcellus ML, Marks MP, Levy RP, Do HM, Steinberg GK: Multimodality treatment of giant intracranial arteriovenous malformations. Neurosurgery 53(1): 1-11, 2003

6. Hyodoh $\mathrm{H}$, Hori $\mathrm{M}$, Akiba $\mathrm{H}$, Tamakawa $\mathrm{M}$, Hyodoh $\mathrm{K}$, Hareyama M: Peripheral vascular malformations: Imaging, treatment approaches, and therapeutic issues. Radiographics 25(Suppl 1): S159-171, 2005

7. Kacker $A$, Heier $L$, Jones J: Large intraosseous arteriovenous malformation of the maxilla - a case report with review of literature. Int J Pediatr Otorhinolaryngol 52(1): 89-92, 2000

8. Matsuyama A, Aoki T, Hisaoka M, Yokoyama K, Hashimoto $\mathrm{H}$ : A case of intraosseous arteriovenous malformation with unusual radiological presentation of low blood flow. Pathol Res Pract 204(6): 423-426, 2008

9. Pasqualin A, Barone G, Cioffi F, Rosta L, Scienza R, Da Pian $\mathrm{R}$ : The relevance of anatomic and hemodynamic factors to a classification of cerebral arteriovenous malformations. Neurosurgery 28(3): 370-379, 1991

10. Perrelli L, Cina G, Cotroneo AR, Falappa P, Nanni L: Treatment of intraosseous arteriovenous fistulas of the extremities. J Pediatr Surg 29(10): 1380-1383, 1994

11. Wu JK, Bisdorff A, Gelbert F, Enjolras O, Burrows PE, Mulliken JB: Auricular arteriovenous malformation: Evaluation, management, and outcome. Plast Reconstr Surg 115(4): 985-995, 2005 